
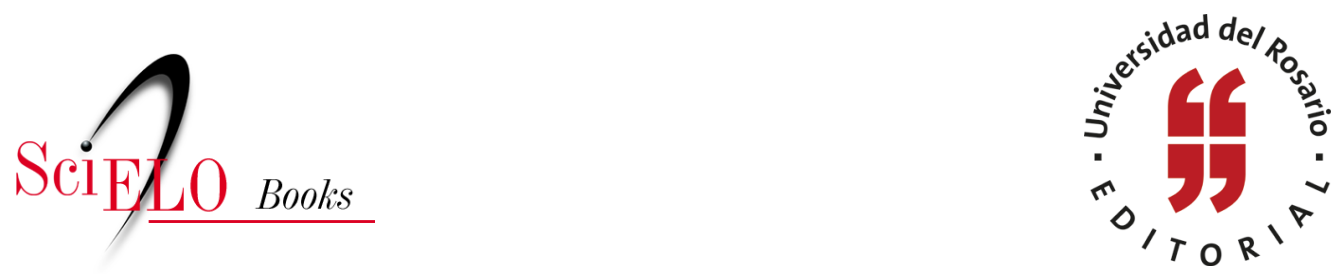

\title{
A manera de prólogo
}

\author{
Sven Schuster (ed.)
}

\section{SciELO Books / SciELO Livros / SciELO Libros}

SCHUSTER, S., ed. A manera de prólogo. In: La nación expuesta. Cultura visual y procesos de formación de la nación en América Latina [online]. Bogotá: Editorial Universidad del Rosario, 2014, pp. ix-xiv. Textos de ciencias humanas collection. ISBN: 978-958-738-524-3. https://doi.org/10.7476/9789587385243.0001.

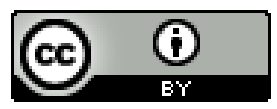

All the contents of this work, except where otherwise noted, is licensed under a Creative Commons Attribution 4.0 International license.

Todo o conteúdo deste trabalho, exceto quando houver ressalva, é publicado sob a licença Creative Commons Atribição 4.0.

Todo el contenido de esta obra, excepto donde se indique lo contrario, está bajo licencia de la licencia Creative Commons Reconocimento 4.0. 


\section{A manera de prólogo}

Desde los años ochenta, un sinnúmero de estudios ha demostrado que la construcción de una comunidad politica imaginada, según la definición de Benedict Anderson, no puede ser analizada sin tomar en consideración aspectos como la génesis del espacio público moderno, el fomento estatal de estructuras administrativas, la infraestructura física, el surgimiento de una literatura nacional y la circulación de medios impresos. Sin embargo, todavía son pocos los trabajos que se refieren explícitamente al papel de las imágenes en este proceso. Con la intención de contribuir a una mejor comprensión de la función de las imágenes para el nation-building, el presente volumen reúne once ensayos originales de disciplinas como la historia, la literatura, los estudios culturales y las ciencias políticas.

¿Qué función cumplen las imágenes de lo propio y de lo ajeno en el proceso de la formación del Estado-nación? ¿Qué papel desempeñan estas imágenes dentro de exposiciones, museos y en el marco de celebraciones públicas, o sea, en su función de "imágenes públicas”? ¿Por qué, cómo y por quién son integradas en discursos nacionalistas? ¿Cuáles son las conexiones transversales que existen entre el poder político, los museos, las exposiciones, los medios de comunicación y las ciencias, y cómo pueden ser analizadas?

Estas son algunas de las preguntas básicas que en su conjunto forman el marco temático de este tomo, las cuales se inspiran en una corriente de estudios sobre lo visual y el poder de las imágenes, que ha experimentado un auge inmenso en el curso del asíllamado giro pictórico (W.J. T. Mitchell) o giro icónico (Gottfried Boehm). Por lo general, se trata de analizar las convenciones y códigos que subyacen a imágenes materiales o mentales (images), así como sus usos, su recepción y su apropiación. $\mathrm{Al}$ igual que los representantes de esta corriente, los colaboradores de este volumen resaltan el hecho de que ciertas imágenes y visualizaciones pueden extenderse al espacio público, donde ejercen un poder político dentro de contextos históricos y 
sociales definidos. Tales "imágenes del poder" no solo reflejan el "espíritu de una época”, sino también lo definen de manera productiva.

Para hacer visible el funcionamiento y la recepción de las imágenes públicas, los textos aquí reunidos combinan métodos de lectura iconográfica ya "clásicos" con el análisis del discurso y otros acercamientos que transcienden los límites disciplinarios. El objetivo es dejar atrás una exploración convencional del contexto histórico y social para poner el relieve en delimitar y remarcar discursivamente las imágenes, pues el enfoque de cualquier interpretación ha de estar en el análisis de la situación comunicativa entre la imagen y el perceptor. De esta manera, se manifiestan las complejas relaciones de poder y las reglas discursivas transmitidas por las imágenes.

En todo caso, el significado de las imágenes públicas se genera siempre por prácticas discursivas, las cuales son más que una simple representación del discurso, pues a la vez definen este último. Por eso la interpretación iconográfica tiene que tomar en cuenta el funcionamiento de las instituciones sociales y políticas, así como las convenciones culturales específicas de cada época. Por lo tanto, también hay que considerar la intermedialidad de las imágenes, las cuales están relacionadas en su mayoría de forma productiva con textos u otras imágenes.

Una primera indagación sobre la función de las imágenes en el proceso de la formación de las naciones latinoamericanas nos ofrece Hans-Joachim König en su ensayo introductorio. Al analizar la creación de símbolos nacionales por los próceres de la Nueva Granada, König parte de teorías de la imagología y de la psicología social, diferenciando entre imágenes tanto mentales como materiales. Otro aspecto destacado de su ensayo está en el empleo de estas imágenes en la retórica política, haciendo hincapié en la metáfora de la familia (o sea, la relación "familiar" entre España y sus colonias), el indio como símbolo de la esclavitud o libertad, según fuera el caso, el árbol de la libertad, y en la figura del ciudadano.

A continuación, Jens Andermann explora cómo justamente ese legado colonial mencionado por König, es decir, el sentimiento de pertenencia entre la "Madre Patria" y sus hijos rebeldes, fue contestado por los fundadores de los nuevos museos nacionales en la época postindependentista. Según él, la misión de los museos latinoamericanos del siglo XIX era la de crear un relato de origen para el Estado-nación emergente al separarlo de la "prehistoria”, entendida como un pasado mítico, y al mismo tiempo evocando una ruptura entre el Estado independiente y su genealogía colonial. Además, estos museos, los cuales en sus comienzos privilegiaron la historia natural, tenían la función de definir el territorio nacional por medio de la colección 
y la visualización. Servían entonces para proyectar simbólicamente el poder de un Estado, cuyos límites geográficos aún no estaban establecidos. Hacia finales del siglo XIX, como se ejemplifica en los casos de Argentina y Brasil, los museos nacionales se transformaban gradualmente en museos explícitamente históricos. Los relatos nacionales que se transmitieron en esa fase ya no se basaban tanto en la distancia entre lo "otro" y el ciudadano capitalino, sino más bien en la aproximación e identificación del espectador con los objetos expuestos. De esta manera, los museos de historia natural, los cuales también eran importantes instituciones de investigación científica, cumplían cada vez más la función de "aparatos ideológicos del Estado", con el fin de educar a la ciudadanía en los valores patrios.

Asimismo, preguntado por el papel de los museos en la creación de imaginarios nacionales, Sven Schuster aborda la conexión entre memoria y cultura visual en Colombia. Aunque la guerra civil de los años cincuenta y sesenta, la asíllamada Violencia, haya representado una ruptura en la historia política del siglo $\mathrm{xx}$, no ha dejado muchas marcas en la memoria histórica de ese país. Como Schuster muestra a partir de pinturas y exposiciones, la época fue frecuentemente reducida a los hechos del 9 de abril de 1948 — día del asesinato del líder liberal Jorge Eliécer Gaitán y la consiguiente destrucción de Bogotá-y así resalta la dimensión urbana de un conflicto que afectó, ante todo, a la población rural. A pesar del deseo de la élite política de encubrir los hechos sangrientos de la Violencia, aprovechándose de la dilución de los sucesos más abominables en la figura de Gaitán, también hay en la actualidad intentos por visualizar la época de una manera más profunda y crítica, como se comprueba en el nuevo Centro de la Memoria de Bogotá. Al mismo tiempo, sin embargo, el reduccionismo ahistórico sigue vigente, simbolizado por el reciente renombramiento del 9 de abril en Día Nacional de la Memoria y de la Solidaridad con las Víctimas.

Las exposiciones y su importancia en el proceso de forjar una autoimagen nacional supuestamente "autóctona" inspiran los siguientes ensayos de Sylvia Dümmer Scheel y Margarida de Souza Neves. Ambas autoras analizan la participación de países latinoamericanos en las grandes exposiciones universales. En el caso del Brasil decimonónico, Neves pregunta hasta qué punto las élites brasileñas consiguieron transmitir la imagen de una "nación moderna" por medio de la participación en las grandes ferias mundiales de Europa y Estados Unidos. Enfocándose en la dimensión performativa y visual de las exposiciones, sostiene que una lectura profunda de los objetos e imágenes expuestos en los "escaparates del progreso" deja entrever las contradicciones de un país, cuya realidad se caracterizaba por realidades socia- 
les poco "progresivas", como la esclavitud y el predominio del modelo económico agroexportador.

En el caso de Chile, analizado por Dümmer, podemos constatar algo muy parecido. Para el país austral, la participación en la Exposición Iberoamericana de Sevilla, en 1929, también ofrecía la posibilidad de poner en escena la imagen de un país civilizado y progresivo, aunque menos "europeizado" como solía ser el caso en las exposiciones del siglo XIX. Después de la primera guerra mundial y la gradual pérdida de atracción del modelo cultural europeo, países como Chile intentaron destacarse más por su carácter "autóctono" y "americano". En este sentido, la construcción de la autoimagen chilena en Sevilla se caracterizó por la revalorización de la "raza", haciendo hincapié en exposiciones etnográficas. No obstante, la exaltación de las extraordinarias características de la supuesta "raza chilena", oriunda de un "país frío", o sea, dotado de un clima semejante al europeo, fue superficial. Lo "autóctono" fue instrumentalizado para servir de base a un relato de origen, en el cual la propia élite criolla apareció como el producto final de un largo proceso teleológico. En esta narración, escenificada en las salas de la exposición, las representaciones de los indígenas servían en primer lugar para mostrar el inicio de ese proceso civilizatorio, ocultar la situación socioeconómica real de grandes partes de la población y separar la cultura indígena viva de una supuesta "antigüedad chilena” gloriosa.

Volviendo a Brasil, Georg Wink repasa los intentos de la élite política de la Primera República por crear un nuevo imaginario nacional después de la caída de la monarquía en 1889. Por medio de una variedad de monumentos e "imágenes públicas", muestra que la deseada reinterpretación de la iconografía imperial no siempre estaba libre de tensiones. Por el contrario, la incoherencia de algunos discursos nacionalistas y su función abiertamente legitimadora del nuevo régimen provocaron frecuentemente controversias. En algunos casos, incluso, los espectadores no mostraron ningún respeto hacia los símbolos del nuevo poder y dotaron los monumentos expuestos de un sentido completamente diferente.

El siguiente trabajo, de Beatriz González Stephan, es igualmente pionero, ya que no solo emprende un análisis formal de diferentes cartes de visite de la Venezuela decimonónica, sino que explora la incorporación de estas en complejos discursos visuales, cuyo denominador común es el discurso racial de la época. González muestra que estas imágenes eran importantes marcadores de diferencia social en una sociedad permeada por sutiles mecanismos de distinción. Ciertas poses, tipos de ropa y, sobre todo, la pertenencia a la "raza blanca” constituían el capital simbólico considerado imprescindible para la inclusión en la "pardocracia" venezolana. Por 
medio de la "invisibilización” de amas de leche, generalmente mulatas y negras, así como la visualización del "blanqueamiento" en algunos autorretratos fotográficos, González muestra cómo la categoría de la "raza” era, de hecho, bastante moldeable.

A continuación, Henio Hoyo se dedica a un tipo de imágenes todavía muy poco exploradas, las estampillas postales. Aunque su trabajo se enfoque también en la propia iconografía de los “embajadores de papel”, le da igual importancia a su circulación para poder analizar su función política y cultural en el proceso de formación de la nación en el México posrevolucionario. Por medio de cortes transversales en el tiempo, Hoyo consigue contextualizar los motivos de las estampillas con los discursos políticos específicos de cada época, poniendo al descubierto la relación simbiótica entre el poder estatal y la imagen pública.

La estrecha relación entre el poder estatal y el empleo de imágenes politizadas también forma el eje temático del ensayo de Ori Preuss. En el centro de su análisis están los estereotipos nacionales construidos y evocados visualmente por la prensa argentina y brasileña entre 1902 y 1912. En este sentido, Preuss muestra cómo las diferentes imágenes del "otro" estaban lejos de ser estáticas, pues oscilaron más bien entre admiración, comprensión y miedo. Aparte de eso, destaca los contextos políticos de cada imagen y caricatura, por ejemplo, el expansionismo brasileño del comienzo del siglo y las reacciones que este provocó en los países vecinos.

Mapas, geodesia y geografía están en el centro del análisis de Ernesto Capello, más específicamente: su papel en la constitución del imaginario nacional en Ecuador entre los siglos XVIII y XX. Lo novedoso del acercamiento de Capello al uso de las ciencias del territorio resulta en la vinculación de estos saberes a los diferentes discursos del poder político. Así, se destaca la gran importancia de la cartografía para el Estado moderno, el cual muy a menudo se aprovechaba de la supuesta objetividad del mapa con el fin de territorializar el espacio. Por medio de comisiones geodésicas y la creación de mapas del territorio nacional el Estado, procuró naturalizar su control espacial de manera discursiva y militar. La reconstrucción de ese proceso, comenzando con un recuento de los antecedentes cartográficos y las primeras misiones geodésicas, estaría sin embargo incompleta si no se mencionaran también las múltiples formas de resistencia que encontró la proyección del poder estatal sobre el espacio.

Finalmente, el texto de Christian Wehr analiza un roadmovie mexicano de 2001: Y tu mamá también, de Alfonso Cuarón. Por medio de un cuidadoso análisis formal, apoyándose eventualmente en el psicoanálisis, muestra cómo la película consigue trazar conexiones sutiles entre el madurar de dos adolescentes y estructuras 
históricas más profundas y de "larga duración” como telón de fondo, culminando en la pérdida del poder del Partido Revolucionario Institucional (PRI) después de más de setenta años en el gobierno. Al final, se desentrañan los diferentes niveles de la película, echando una mirada aguda sobre una sociedad desconcertada e insegura de su destino. En este sentido, la película se parece con una fotografía instantánea, la cual quedará como un lugar de memoria al congelar el estado de la nación en ese instante histórico.

Agradezco a todas las autoras y a todos los autores su colaboración para la realización de este tomo. También doy las gracias a Fernanda Pan, Érika Herrero, Alejandra Sánchez, Andrés Vargas y Natalia Gutiérrez por la corrección de pruebas, el control de fuentes y la edición del material gráfico, así como al equipo de la Editorial de la Universidad del Rosario, por su apoyo.

Sven Schuster

Bogotá, julio de 2014 